\title{
SYNTHESIS, CHARACTERISATION AND ANTIMICROBIAL STUDIES OF MIXED NICKEL(II) AND COPPER(II) COMPLEXES OF AROYLHYDRAZONES WITH 2, 2 - BIPYRIDINE AND 1, 10-PHENANTHROLINE
}

\author{
Ajayeoba, T. A., Akinyele, O. F. and Oluwole, A. O. \\ Department of Chemistry, Obafemi Awolowo University, Ile-Ife Nigeria \\ Corresponding Author: Akinyele, O.F.Email: ofakinyele@oauife.edu.ng,ofakins@yahoo.com \\ (Received: April, 2017; Accepted: July, 2017)
}

\section{ABSTRACT}

\begin{abstract}
Herein, we report the synthesis of 2-anisaldehyde-benzoylhydrazone $\left(\mathrm{L}_{1}\right)$, vanillin-benzoylhydrazone $\left(\mathrm{L}_{2}\right)$ and mixed $\mathrm{Ni}(\mathrm{II})$ and $\mathrm{Cu}(\mathrm{II})$ complexes of $\mathrm{L}_{1}$ and $\mathrm{L}_{2}$ with 2, $2^{1}$-bipyridine and 1, 10-phenanthroline (N-N bases). The resulting compounds were characterized by ${ }^{1} \mathrm{H}$ NMR, IR, UV-VIS, Solubility studies, percentage Metal analysis, Conductivity measurements, and Magnetic Moment measurements. ${ }^{1} \mathrm{H}$ NMR spectra indicated the formation of the ligands. IR Spectra showed that the ligands coordinated in enol form through the deprotonated carbonyl bond $(\mathrm{C}=\mathrm{O})$ and the azomethine $(\mathrm{C}=\mathrm{N})$. The $(\mathrm{N}-\mathrm{N})$ bases similarly coordinated through the $(\mathrm{C}=\mathrm{N})$. The magnetic moment values for the $\mathrm{Cu}$ (II) complexes ranges from 2.14 to 2.36 B.M Magnetic moment values ranging from 2.78 to 3.11 B.M were found for the complexes of Nickel except $\left[\mathrm{Ni}\left(\mathrm{L}_{2}\right)(\mathrm{bpy})\right] \mathrm{Cl}$ and $\left[\mathrm{Ni}\left(\mathrm{L}_{2}\right)\right.$ phen] $\mathrm{Cl}$ that had moment of 0.49 and 0.75 B.M respectively. Conductance values indicated a $1: 1$ electrolyte for the complexes. The antimicrobial activities of the ligands and their mixed ligand complexes were screened using Agar diffusion method. It was found that the mixed metal complexes have higher antimicrobial activity than the free ligands.
\end{abstract}

Keywords: Benzylhydrazone, Spectroscopy, Magnetic moment, Geometry, Zone of inhibition.

\section{INTRODUCTION}

Hydrazones are a class of organic compounds that are characterized with the presence of $\mathrm{R}_{1} \mathrm{R}_{2} \mathrm{C}=\mathrm{N}-\mathrm{NH}$ - atomic linkage. They are formed by the condensation of hydrazides or hydrazide derivatives with aldehydes or ketones (Deepa and Aravindakshan, 2005). They contain two connected nitrogen atoms of different nature and an azomethine $(\mathrm{C}=\mathrm{N})$ that is conjugated with a lone pair of electrons of the terminal nitrogen atom (Walcourt et al., 2004). These structural fragments are mainly responsible for the physical and chemical properties of the compounds. The two nitrogen atoms of these groups of compounds are nucleophilic, although, the amino nitrogen is more reactive. The carbon atoms of hydrazone group are both electrophilic and nucleophilic in character hence; they are widely used in organic synthesis, especially for the preparation of heterocyclic compounds. The ease of preparation, increased hydrolytic stability relative to imines, and tendency toward crystallinity are characteristics that make hydrazones desirable (Wang et al., 2013).

Hydrazones have interesting biological properties, which include anti-inflammatory and antimalarial (Fattorusso et al., 2008), analgesic, anticonvulsant, antituberculous, antitumor (Al-Said et al., 2011), anti-HIV and antimicrobial activities, hence they constitute an important class of compounds for new drug development (Rollas and Kucukguzel, 2007; Gokce et al., 2009; Ahmed et al., 2014). There are several reports on the synthesis, structural characterization and biological activities of transition metal complexes containing different types of hydrazone ligands (Shen and Jiang, 1995; Galal et al., 2009; Hosny et al., 2010; Agwapa et al., 2010;). Mixed chelates of Aroylhydrazones with base ligand such as 1,10phenanthroline, 2, 2-bipyridine (Niu et al., 2007) and 2-amino-4-methylpyridine (Sreeja et al., 2004) have been reported and found to exhibit enhanced antimicrobial properties than the metal(II) complexes. However, report on synthesis, physicochemical studies and antimicrobial activity of mixed $\mathrm{Ni}(\mathrm{II})$ and $\mathrm{Cu}(\mathrm{II})$ complexes of 2-anisaldehyde-benzoylhydrazone $\left(\mathrm{L}_{1}\right)$, vanillin-benzoylhydrazone $\left(\mathrm{L}_{2}\right)$ with $2,2^{1}$ bipyridine and 1, 10-phenanthroline are scanty. The results of this study are herein reported. 


\section{EXPERIMENTAL}

\section{Reagents and solvents}

All the chemicals and solvents employed were of $\mathrm{BDH}$ and Sigma Aldrich quality and used without further purification. They are Ethylbenzoate, Vanillin (3-methoxy-4-hydroxyl-benzaldehyde), 2-Anisaldehyde (2-methoxy-benzaldehyde), ethylenediaaminetetraacetic acid (disodium salt), Dimethylsulphoxide (DMSO), Dimethylformamide (DMF), Acetone, Diethylether, Methanol, Ethanol, Hydrazine hydrate. Copper (II) chloride dihydrate and Nickel(II) chloride hexahydrate. The metal contents (w/w \%) were determined by complexometric titration of EDTA using murexide indicator and ammonia/ammonium chloride buffer. IR Spectra were recorded in the range 4000-400 $\mathrm{cm}^{-1}$ using $\mathrm{KBr}$ discs on Shimadzu FT-IR 8000 Spectrometer at Redeemer's University, Ede, Osun State. UV-Vis spectra of the samples were measured in the range $1000-$ $200 \mathrm{~cm}^{-1}$ using a Shimadzu UV-Vis 1800 Spectrophotometer at Central Science Laboratory, Obafemi Awolowo University, Ile-Ife, Nigeria. The magnetic susceptibility of the samples was measured with a Sherwood Scientific Magnetic susceptibility balance, MSB Mark1 at University of Ibadan, Nigeria. Melting Points of the compounds were determined using a Gallenkamp melting point Apparatus at Obafemi Awolowo University, Ile-Ife, Nigeria.

\section{Synthesis of Hydrazone}

The preparation of the Hydrazone was done in two steps: the first step involved the preparation of the Benzoyl hydrazide, while the second step yielded the Hydrazones.

\section{Preparation of Hydrazide}

Ethylbenzoate $(63 \mathrm{ml}, 400 \mathrm{mmol})$ in $70 \mathrm{ml}$ ethanol and hydrazine hydrate $(19.40 \mathrm{ml}, 400 \mathrm{mmol})$ in 15 $\mathrm{ml}$ of ethanol were mixed in a $250 \mathrm{ml}$ round bottom flask and the mixture was heated under reflux for 12 hours. The resultant yellow solution was concentrated using rotary evaporator to obtain a white crystalline precipitate which was washed several times with $40 \%$ ethanol to obtain white crystalline solid. It was dried in the desiccator over $\mathrm{CaCl}_{2}$ M.pt. $110-112^{\circ} \mathrm{C}$

\section{Synthesis of Hydrazone [VBH $\left(\mathrm{L}_{2}\right)$ ]}

Benzoylhydrazide ( $0.3 \mathrm{~g}, 0.22 \mathrm{mmol}$.) in $20 \mathrm{ml}$ of absolute ethanol was added dropwise into $20 \mathrm{ml}$ of ethanolic solution of 4-hydroxy-3methoxybenzaldehyde $(3.35 \mathrm{~g}, 0.22 \mathrm{mmol})$. The mixture was stirred and refluxed for 4 hours. The mixture was left overnight in a beaker to form precipitate after which the white crystalline precipitate was filtered and washed with $40 \%$ ethanol and dried in a desiccator over $\mathrm{CaCl}_{2}$. The same method was used for $\mathrm{L}_{1}(2-\mathrm{ABH})$.

\section{Preparation of Metal(II) Hydrazone Mixed with 1,10-Phenanthroline}

The ligands $\left(\mathrm{L}_{1} / \mathrm{L}_{2}\right),(1.1 \mathrm{mmol})$ were dissolved in $(10 \mathrm{ml})$ of $1: 1 \mathrm{absolute}$ ethanol/acetone mixture in a $100 \mathrm{ml}$ beaker and allowed to stir for 10 minutes. Then, an ethanolic solution of metal(II)chlorides $(1.1 \mathrm{mmol})$ and ethanolic solution of 1,10 -phenanthroline $(1.1 \mathrm{mmol})$ were simultaneously added dropwise to the stirring mixture. The mixtures were stirred for $6 \mathrm{hrs}$ at room temperature after which the precipitate formed was filtered and washed using 40\% ethanol and dried in a desiccator over calcium chloride.

$\mathrm{L}_{1} / \mathrm{L}_{2}+\mathrm{MCl}_{2} \cdot \mathrm{xH}_{2} \mathrm{O}+\mathrm{phen} \rightarrow$ $\left[\mathrm{M}\left(\mathrm{L}_{1} / \mathrm{L}_{2}\right)(\right.$ phen $\left.)\left(\mathrm{H}_{2} \mathrm{O}\right)_{2}\right] \mathrm{Cl}+\mathrm{HCl}+\mathrm{xH}_{2} \mathrm{O}$

\section{Synthesis of Metal(II) Hydrazone Mixed with 2,2-Bipyridine}

The ligands, $\mathrm{L}_{1} / \mathrm{L}_{2}(1.1 \mathrm{mmol})$ were dissolved in a $1: 1$ ethanol/acetone mixture $(10 \mathrm{ml})$ in a $100 \mathrm{ml}$ beaker and allowed to stir for 10 minutes after which an ethanolic solution of metal(II) chloride $(1.1 \mathrm{mmol})$ and ethanolic solution of $2,2^{1}$ bipyridine $(1.1 \mathrm{mmol}$ ) was added dropwise to the stirring mixture. The reaction mixture was stirred at room temperature for 2 to 6 hours after which the precipitate were filtered under suction, washed with $40 \%$ ethanol and dried in a desiccator over $\mathrm{CaCl}_{2}$.

$\mathrm{L}_{1} / \mathrm{L}_{2}+\mathrm{MCl}_{2} .6 \mathrm{H}_{2} \mathrm{O}+$ bipy $\rightarrow$ $\left[\mathrm{Ni}\left(\mathrm{L}_{1} / \mathrm{L}_{2}\right)(\right.$ bipy $\left.)\right] \mathrm{Cl}+\mathrm{HCl}+\mathrm{xH}_{2} \mathrm{O}$

\section{RESULTS AND DISCUSSION}

\section{General comments.}

Nickel(II) and Copper(II) complexes of aroylhydrazones mixed with $2,2^{1}$ - bipyridine and 
1,10- phenanthroline have been prepared according to method described in the literature (Patel and Woods, 1990; Wang et al., 2008; Singh and Singh, 2012) and were characterized with a view of proposing their geometry and stoichiometry. Physicochemical properties of the compounds including colour, melting point/decomposition temperature and percentage yields, are presented in Table 1 . The two ligands $\left(\mathrm{L}_{1}\right.$ and $\left.\mathrm{L}_{2}\right)$ synthesized are white. The mixed ligand copper(II) complexes with 2,2 bipyridine and 1,10-phenathroline are generally green while nickel(II) complexes mixed with $2,2^{1}$ bipyridine and 1,10-phenanthroline respectively display colours ranging from orange to deep green. The melting point of $\mathrm{L}_{1}$ is $193-195^{\circ} \mathrm{C}$ and $\mathrm{L}_{2}$ is $128-130^{\circ} \mathrm{C}$. All the mixed metal(II) complexes of $2-\mathrm{ABH}\left(\mathrm{L}_{1}\right)$ have melting point in the range of $251-269^{\circ} \mathrm{C}$ while the mixed complexes of $\mathrm{VBH}$ $\left(\mathrm{L}_{2}\right)$ ranges from 269 to $285^{\circ} \mathrm{C}$ indicating high thermal stabilities for the complexes.

There was a fair agreement between the calculated $\%$ metal and the observed for the metal complexes. The results suggested a ratio 1:1:1 for metal to ligand to base. The compounds are fairly soluble in methanol, DMF and DMSO with varying degree of solubility in the eight common solvents. These physico-chemical parameters are shown in Table 1, while their solubilities are displayed in Table 2.

\section{${ }^{1} \mathbf{H}-\mathbf{N M R}$}

The ${ }^{1} \mathrm{H}-\mathrm{NMR}$ in DMSO- $\mathrm{d}_{6}$ of $\mathrm{L}_{1}$ (Figure 1a, Appendix) shows multiplet signals in the range 6.91 to $7.90 \mathrm{ppm}$ due to aromatic protons. The signal at $8.70 \mathrm{ppm}(1 \mathrm{H}, \mathrm{s})$ is due to the azomethine proton $(\mathrm{HC}=\mathrm{N}-)$. The signal at $10.50 \mathrm{ppm}(1 \mathrm{H}, \mathrm{s})$ corresponds to the amide type N-H Proton. The signal at $3.90 \mathrm{ppm}(3 \mathrm{H}, \mathrm{s})$ correspond to the methoxy group $\left(-\mathrm{OCH}_{3}\right)$ while the signal at 2.10 $\mathrm{ppm}$ is due to the solvent proton.

The ${ }^{1} \mathrm{H}-\mathrm{NMR}$ of the $\mathrm{L}_{2}$ in DMSO- $\mathrm{d}_{6}$ (Figure $1 \mathrm{~b}$ ) shows multiplet signals in the range 6.86 to 7.90 ppm which corresponds to the aromatic protons. The signal at $3.84 \mathrm{ppm}(3 \mathrm{H}, \mathrm{s})$ correspond to the proton of methoxy $\left(-\mathrm{OCH}_{3}\right)$ group while the amide type proton $(\mathrm{N}-\mathrm{H})$ appeared at $11.68 \mathrm{ppm}$. The signal at $8.30 \mathrm{ppm}(1 \mathrm{H}, \mathrm{s})$ is due to the azomethine proton $(\mathrm{HC}=\mathrm{N}-)$, while the signal at $2.50 \mathrm{ppm}$ and $3.30 \mathrm{ppm}$ are the solvent peaks.

Table 1: Physical properties and analytical data for the complexes

\begin{tabular}{|l|l|l|l|l|l|}
\hline Complex & $\begin{array}{l}\text { Formula ( Formula } \\
\text { weight }(\mathrm{g} / \text { mol })\end{array}$ & Colour & $\begin{array}{l}\text { Melting } \\
\left.\text { point. }{ }^{\circ} \mathrm{C}\right)\end{array}$ & $\begin{array}{l}\text { \% Metal found } \\
(\text { Calculated })\end{array}$ & \% Yield \\
\hline $2-\mathrm{ABH}\left(\mathrm{L}_{1}\right)$ & $\mathrm{C}_{15} \mathrm{H}_{14} \mathrm{~N}_{2} \mathrm{O}_{2}(254.34)$ & White & $193-195$ & & 88 \\
\hline$\left[\mathrm{Cu}\left(\mathrm{L}_{1}\right)(\mathrm{bpyy})\left(\mathrm{H}_{2} \mathrm{O}\right)_{2}\right] \mathrm{Cl}$ & $\begin{array}{l}\mathrm{C}_{25} \mathrm{H}_{26} \mathrm{~N}_{4} \mathrm{O}_{4} \mathrm{ClCu} \\
(545.50)\end{array}$ & Green & $256-258$ & $12.48(12.71)$ & 28 \\
\hline$\left[\mathrm{Cu}\left(\mathrm{L}_{1}\right)(\right.$ phen $\left.)\left(\mathrm{H}_{2} \mathrm{O}\right)_{2}\right] \mathrm{Cl}$ & $\begin{array}{l}\mathrm{C}_{27} \mathrm{H}_{26} \mathrm{~N}_{4} \mathrm{O}_{4} \mathrm{ClCu} \\
(569.52)\end{array}$ & Green & $266-269$ & $11.53(12.10)$ & 43 \\
\hline$\left[\mathrm{Ni}\left(\mathrm{L}_{1}\right)(\right.$ bpy $\left.)\left(\mathrm{H}_{2} \mathrm{O}\right)_{2}\right] \mathrm{Cl}$ & $\begin{array}{l}\mathrm{C}_{25} \mathrm{H}_{26} \mathrm{~N}_{4} \mathrm{O}_{4} \mathrm{ClNi} \\
(540.64)\end{array}$ & $\begin{array}{l}\text { Deep } \\
\text { green }\end{array}$ & $251-253$ & $12.00(11.74)$ & 22 \\
\hline$\left[\mathrm{Ni}\left(\mathrm{L}_{1}\right)(\right.$ phen $\left.)\left(\mathrm{H}_{2} \mathrm{O}\right)_{2}\right] \mathrm{Cl}$ & $\begin{array}{l}\mathrm{C}_{27} \mathrm{H}_{26} \mathrm{~N}_{4} \mathrm{O} 4 \mathrm{ClNi} \\
(546.42)\end{array}$ & $\begin{array}{l}\text { Deep } \\
\text { green }\end{array}$ & $261-263$ & $10.74(11.00)$ & 19 \\
\hline $\mathrm{VBH}\left(\mathrm{L}_{2}\right)$ & $\mathrm{C}_{15} \mathrm{H}_{14} \mathrm{~N}_{2} \mathrm{O}_{3}(270.28)$ & White & $128-130$ & & 84 \\
\hline$\left[\mathrm{Cu}\left(\mathrm{L}_{2}\right)(\right.$ bpy $\left.)\left(\mathrm{H}_{2} \mathrm{O}\right)_{2}\right] \mathrm{Cl}$ & $\begin{array}{l}\mathrm{C}_{25} \mathrm{H}_{26} \mathrm{~N}_{4} \mathrm{O}_{5} \mathrm{ClCu} \\
(561.50)\end{array}$ & Green & $282-285$ & $12.09(12.48)$ & 48 \\
\hline$\left[\mathrm{Cu}\left(\mathrm{L}_{2}\right)(\right.$ phen $\left.)\left(\mathrm{H}_{2} \mathrm{O}\right)_{2}\right] \mathrm{Cl}$ & $\begin{array}{l}\mathrm{C}_{27} \mathrm{H}_{26} \mathrm{~N}_{4} \mathrm{O}_{5} \mathrm{ClCu} \\
(585.52)\end{array}$ & Green & $275-278$ & $11.19(10.85)$ & 41 \\
\hline$\left[\mathrm{Ni}\left(\mathrm{L}_{2}\right)(\right.$ bpy $\left.)\right] \mathrm{Cl}$ & $\begin{array}{l}\mathrm{C}_{25} \mathrm{H}_{22} \mathrm{~N}_{4} \mathrm{O}_{3} \mathrm{ClNi} \\
(520.61)\end{array}$ & Orange & $277-279$ & $11.30(11.64)$ & 28 \\
\hline$\left[\mathrm{Ni}\left(\mathrm{L}_{2}\right)(\right.$ phen $\left.)\right] \mathrm{Cl}$ & $\begin{array}{l}\mathrm{C}_{27} \mathrm{H}_{22} \mathrm{~N}_{4} \mathrm{O}_{3} \mathrm{ClNi} \\
(544.63)\end{array}$ & Orange & $269-271$ & $10.43(10.61)$ & 41 \\
\hline
\end{tabular}


Table 2: Solubility data for the complexes

\begin{tabular}{|l|l|l|l|l|l|l|l|l|}
\hline Compounds & $\mathbf{H}_{2} \mathbf{O}$ & EtOH & MeOH & DCM & DMSO & DMF & Acetone & Diethylether \\
\hline $\mathrm{L}_{1}$ & I & SS & S & SS & S & S & S & I \\
\hline$\left[\mathrm{Cu}\left(\mathrm{L}_{1}\right)(\right.$ bpy $\left.)\left(\mathrm{H}_{2} \mathrm{O}\right)_{2}\right] \mathrm{Cl}$ & I & S & S & I & S & S & S & I \\
\hline$\left[\mathrm{Cu}\left(\mathrm{L}_{1}\right)(\right.$ phen $\left.)\left(\mathrm{H}_{2}\right)_{2}\right] \mathrm{Cl}$ & I & S & SS & I & S & S & S & I \\
\hline$\left[\mathrm{Ni}\left(\mathrm{L}_{1}\right)(\right.$ bpy $)\left(\mathrm{H}_{2} \mathrm{O}_{2}\right] \mathrm{Cl}$ & I & S & S & SS & S & S & S & I \\
\hline$\left[\mathrm{Ni}\left(\mathrm{L}_{1}\right)(\right.$ phen $\left.)\left(\mathrm{H}_{2} \mathrm{O}\right)_{2}\right] \mathrm{Cl}$ & I & S & S & I & S & S & SS & I \\
\hline $\mathrm{L}_{2}$ & I & S & S & SS & S & S & S & SS \\
\hline$\left[\mathrm{Cu}\left(\mathrm{L}_{2}\right)(\right.$ bpy $\left.)\left(\mathrm{H}_{2} \mathrm{O}\right)_{2}\right] \mathrm{Cl}$ & I & S & S & I & S & S & S & I \\
\hline$\left[\mathrm{Cu}\left(\mathrm{L}_{2}\right)(\right.$ phen $\left.)\left(\mathrm{H}_{2} \mathrm{O}\right)_{2}\right] \mathrm{Cl}$ & I & S & S & I & S & S & SS & I \\
\hline$\left[\mathrm{Ni}\left(\mathrm{L}_{2}\right)(\right.$ bpy $\left.)\right] C l$ & I & S & S & I & S & S & S & I \\
\hline$\left[\mathrm{Ni}\left(\mathrm{L}_{2}\right)(\right.$ phen $\left.)\right] C l$ & I & S & S & I & S & S & S & I \\
\hline
\end{tabular}

I: Insoluble, S: Soluble, SS: Sparingly soluble

\section{Infrared Spectra}

The structurally significant IR bands for free ligand and its complexes are reported in Table 3. The diagnostic and relevant vibrational frequencies obtained from the spectra of the compounds are assigned to fundamental vibrational modes based on literature reports on similar compounds (Deepa and Aravindakshan, 2005; Singh and Singh, 2012). The infrared spectra of the ligands were compared to that of the metal complexes to observe the shifts in bands which could provide an evidence of coordination to the metal ion (Neelammaa et al, 2010).

In the synthesized hydrazone ligands $\left(\mathrm{L}_{1}\right.$ and $\left.\mathrm{L}_{2}\right)$, the bands at $3441 \mathrm{~cm}^{-1}$ and $3485 \mathrm{~cm}^{-1}$ are assigned to $\mathrm{v}\left(\mathrm{OH} / \mathrm{H}_{2} \mathrm{O}\right)$ vibrational frequency for both $\mathrm{L}_{1}$ and $\mathrm{L}_{2}$ respectively while the band at $3244 \mathrm{~cm}^{-1}$ in $\mathrm{L}_{1}$ and $3242 \mathrm{~cm}^{-1}$ in $\mathrm{L}_{2}$ is assigned for $\mathrm{v}(\mathrm{N}-\mathrm{H})$ vibrational frequencies. The carbonyl stretching frequencies band $v(\mathrm{C}=\mathrm{O})$ occurred at 1639 and $1637 \mathrm{~cm}^{-1}$ for $\mathrm{L}_{1}$ and $\mathrm{L}_{2}$ respectively.

The azomethine bands $\mathrm{v}(\mathrm{C}=\mathrm{N})$ which is the other point of coordination occurs in the range 1514 to $1541 \mathrm{~cm}^{-1}$ for the ligands, while the bands at 1024 $\mathrm{cm}^{-1}$ and $1022 \mathrm{~cm}^{-1}$ are assigned to $\mathrm{v}(\mathrm{N}-\mathrm{N})$ vibrational frequencies of $2-\mathrm{ABH}$ and $\mathrm{VBH}$ respectively. On complexation, there was the disappearance of the $v(\mathrm{C}=\mathrm{O})$ and the $\mathrm{v}(\mathrm{N}-\mathrm{H})$ bands in both ligands as a result of enolization and subsequent deprotonation which suggest that the ligands coordinated to the metal ion in enol form. A comparison of the infrared spectra of the ligands and its metal complexes mixed with 2,2bipyridine and 1,10-phenanthroline (Table 3) reveals that the ligands are mononegative bidentate, coordinating via the azomethine nitrogen $(\mathrm{C}=\mathrm{N})$ and deprotonated carbonyl oxygen (=C-O) which is evident in the appearance of a new band at $1145-1282 \mathrm{~cm}^{-1}$ due to $(\mathrm{C}=\mathrm{N}-\mathrm{N}=\mathrm{C})$ in all the mixed metal complexes.

The azomethine band $\mathrm{v}(\mathrm{C}=\mathrm{N})$ had a shift ranging from 5 to $50 \mathrm{~cm}^{-1}$ in the complexes which is indicative of the coordination through the azomethine nitrogen $v(\mathrm{C}=\mathrm{N})$ bond to the metal ions. (Chandra and Kumar, 2005). The $v(\mathrm{~N}-\mathrm{N})$ vibrational frequency for both $2-\mathrm{ABH}$ and $\mathrm{VBH}$ shifted on complexation as a result of decrease in electron density on the nitrogen atom. The appearance of new bands in the low frequency region at $536-650 \mathrm{~cm}^{-1}$ and $418-447 \mathrm{~cm}^{-1}$ are attributed to metal to oxygen (M-O) and metal to nitrogen (M-N) bonds respectively are evidence of coordination (Abdel-Aziz et al., 2009). Typical IR spectra of $\mathrm{VBH}\left(\mathrm{L}_{2}\right)$ and mixed $\mathrm{Cu}(\mathrm{II})$ complex are displayed in Figures 2 (Appendix). 
Table 3: Infrared spectra data $\left(\mathrm{cm}^{-1}\right)$ of the hydrazones and their mixed metal (II) complexes

\begin{tabular}{|l|l|l|l|l|l|l|l|l|}
\hline Compounds & $v(\mathrm{O}-\mathrm{H})$ & $v(\mathrm{~N}-\mathrm{H})$ & $v(\mathrm{C}=\mathrm{O})$ & $v(\mathrm{C}=\mathrm{N})$ & $v(\mathrm{C}=\mathrm{N})_{\text {(base })}$ & $v(\mathrm{~N}-\mathrm{N})$ & $v(\mathrm{M}-\mathrm{O})$ & $v(\mathrm{M}-\mathrm{N})$ \\
\hline $\mathrm{L} 1$ & & $3244 \mathrm{~m}$ & $1639 \mathrm{~m}$ & $1541 \mathrm{~m}$ & - & $1024 \mathrm{w}$ & - & - \\
\hline$\left[\mathrm{Cu}\left(\mathrm{L}_{1}\right)\right.$ (bpy) $\left.\left(\mathrm{H}_{2} \mathrm{O}\right)_{2}\right] \mathrm{Cl}$ & $3443 \mathrm{~b}$ & - & - & $1568 \mathrm{~m}$ & $1473 \mathrm{~m}$ & $1026 \mathrm{w}$ & $636 \mathrm{w}$ & $418 \mathrm{w}$ \\
\hline$\left[\mathrm{Cu}\left(\mathrm{L}_{1}\right)(\right.$ phen $\left.)\left(\mathrm{H}_{2} \mathrm{O}\right)_{2}\right] \mathrm{Cl}$ & $3456 \mathrm{~b}$ & - & - & $1516 \mathrm{~m}$ & $1464 \mathrm{~m}$ & $1047 \mathrm{w}$ & $644 \mathrm{w}$ & $428 \mathrm{w}$ \\
\hline$\left[\mathrm{Ni}\left(\mathrm{L}_{1}\right)(\mathrm{bpy})\left(\mathrm{H}_{2} \mathrm{O}\right)_{2}\right] \mathrm{Cl}$ & $3441 \mathrm{~b}$ & - & - & $1492 \mathrm{~m}$ & $1435 \mathrm{~m}$ & $1033 \mathrm{w}$ & $536 \mathrm{w}$ & $447 \mathrm{w}$ \\
\hline$\left[\mathrm{Ni}\left(\mathrm{L}_{1}\right)(\right.$ phen $\left.)\left(\mathrm{H}_{2} \mathrm{O}\right)_{2}\right] \mathrm{Cl}$ & $3450 \mathrm{~b}$ & - & - & $1492 \mathrm{~m}$ & $1435 \mathrm{~m}$ & $1033 \mathrm{w}$ & $650 \mathrm{w}$ & $418 \mathrm{w}$ \\
\hline $\mathrm{L} 2$ & $3485 \mathrm{~m}$ & $3242 \mathrm{~s}$ & $1637 \mathrm{~m}$ & $1514 \mathrm{~m}$ & - & $1022 \mathrm{w}$ & - & - \\
\hline$\left[\mathrm{Cu}\left(\mathrm{L}_{2}\right)\right.$ (bpy) $\left.\left(\mathrm{H}_{2} \mathrm{O}\right)_{2}\right] \mathrm{Cl}$ & $3491 \mathrm{~b}$ & - & - & $1568 \mathrm{~m}$ & $1496 \mathrm{~m}$ & $1026 \mathrm{w}$ & $634 \mathrm{w}$ & $418 \mathrm{w}$ \\
\hline$\left[\mathrm{Cu}\left(\mathrm{L}_{2}\right)(\mathrm{phen})\left(\mathrm{H}_{2} \mathrm{O}\right)_{2}\right] \mathrm{Cl}$ & $3448 \mathrm{~b}$ & - & - & $1526 \mathrm{~m}$ & $1516 \mathrm{~m}$ & $1047 \mathrm{w}$ & $644 \mathrm{w}$ & $430 \mathrm{w}$ \\
\hline$\left[\mathrm{Ni}\left(\mathrm{L}_{2}\right)\right.$ (bipy) $) \mathrm{Cl}$ & $3491 \mathrm{~b}$ & - & - & $1595 \mathrm{~m}$ & $1512 \mathrm{~m}$ & $1039 \mathrm{w}$ & $557 \mathrm{w}$ & $418 \mathrm{w}$ \\
\hline$\left[\mathrm{Ni}\left(\mathrm{L}_{2}\right)\right.$ (phen) $] \mathrm{Cl}$ & $3491 \mathrm{~b}$ & - & - & $1595 \mathrm{~m}$ & $1512 \mathrm{~m}$ & $1039 \mathrm{w}$ & $557 \mathrm{w}$ & $418 \mathrm{w}$ \\
\hline
\end{tabular}

\section{Electronic spectra}

The solution electronic spectra measured in methanol for the synthesized hydrazone ligands and their mixed metal (II) complexes are presented in Table 4. In the ultraviolet spectra of the synthesized ligands $\left(\mathrm{L}_{1}\right.$ and $\left.\mathrm{L}_{2}\right)$, two electronic transitions were prominent. The bands in the range 30,487 to $30,674 \mathrm{~cm}^{-1}$ have been assigned to the $\pi \rightarrow \pi^{*}$ transition in the aromatic system (Singh et al, 2009; Abdel-Wahab et al, 2011). The bands in the range 33,333 to $34,965 \mathrm{~cm}^{-1}$ and 33,112 to $33,333 \mathrm{~cm}^{-1}$ are attributed to the second intraligand transition $\mathrm{n} \rightarrow \pi^{*}$ in the azomethine moiety (Al-sha'alan, 2007; Babahan et al., 2013). Vanillin-benzoylhydrazone $\left(\mathrm{L}_{2}\right)$ showed an additional band at $43,103 \mathrm{~cm}^{-1}$ which is assigned to high energy transition $n \rightarrow \sigma^{*}$ due to excitation of the oxygen lone pair of electron to the antibonding sigma orbital of the hydroxyl group (Dandawante et al, 2012). Upon coordination with complexes of $\mathrm{Cu}$ (II) and $\mathrm{Ni}(\mathrm{II})$ mixed with 2,2bipyridine and 1,10-phenathroline, these intraligand $\pi \rightarrow \pi^{*}$ and $\mathrm{n} \rightarrow \pi^{*}$ electronic transition in the free, uncoordinated $\mathrm{L}_{1}$ and $\mathrm{L}_{2}$ ligands undergo shift in the UV spectra suggesting a strong interaction between the ligands and the metal ion. The visible spectra of $\left[\mathrm{Cu}\left(\mathrm{L}_{1}\right)(\right.$ bpy $\left.)\left(\mathrm{H}_{2} \mathrm{O}\right)_{2}\right] \mathrm{Cl}$, showed one broad, d-d band centered at $14,306 \mathrm{~cm}^{-1}$ and a slight shoulder at $13,422 \mathrm{~cm}^{-1}$ as a result of distortion, while $\left[\mathrm{Cu}\left(\mathrm{L}_{1}\right)\right.$ (phen) $\left.\left(\mathrm{H}_{2} \mathrm{O}\right)_{2}\right] \mathrm{Cl}$ showed a band at 14,619 $\mathrm{cm}^{-1}$. This is consistent with the ${ }^{2} \mathrm{E}_{\mathrm{g}} \rightarrow{ }^{2} \mathrm{~T}_{2 \mathrm{~g}}$ transition in an octahedral environment (Parrilha et al, 2010). The broadening of the band may be due to Jahn-Teller effect arising from unequal occupation of the $e_{\mathrm{g}}$ pair of orbitals. The visible spectra of all the mixed nickel(II) complexes showed three d-d bands at 15,625 $\mathrm{cm}^{-1}, 14,084 \mathrm{~cm}^{-}$ ${ }^{1}$ and $11,834 \mathrm{~cm}^{-1}$ respectively, which are expected for a nickel(II) ion in an octahedral environment corresponding to the transition ${ }^{3} \mathrm{~A}_{2 g} \rightarrow{ }^{3} \mathrm{~T}_{2 g}$ in the range $11,834 \mathrm{~cm}^{-1},{ }^{3} \mathrm{~A}_{2 \mathrm{~g}} \rightarrow{ }^{3} \mathrm{~T}_{1 \mathrm{~g}}$ in the range 14,084 $15,625 \mathrm{~cm}^{-1}$ (Cotton et al, 2003; Singh and Singh, 2012). Three d-d bands were also observed for $\mathrm{Ni}(\mathrm{II})$ complexes of 2 -ABH mixed with 2,2bipyridine at $14,409,12,821$ and $11,710 \mathrm{~cm}^{-1}$ which are also expected for $\mathrm{Ni}(\mathrm{II})$ ion in octahedral environment. However, the visible spectra of $\left[\mathrm{Ni}\left(\mathrm{L}_{2}\right)(\mathrm{bpy})\right] \mathrm{Cl}$ and $\left[\mathrm{Ni}\left(\mathrm{L}_{2}\right)(\right.$ phen $\left.)\right] \mathrm{Cl}$ displayed two d-d bands observed at 19,231 and $15,385 \mathrm{~cm}^{-1}$ and at 15,503 and 13,333 $\mathrm{cm}^{-1}$ respectively, which are consistent with square planar geometry and are assigned to ${ }^{1} \mathrm{~A}_{1 \mathrm{~g}} \rightarrow{ }^{1} \mathrm{~A}_{2 \mathrm{~g}}\left(\mathrm{~b}_{2 \mathrm{~g}} \rightarrow \mathrm{b}_{1 \mathrm{~g}}\right)$ and ${ }^{1} \mathrm{~A}_{1 \mathrm{~g}} \rightarrow$ ${ }^{1} \mathrm{~B}_{1 \mathrm{~g}}\left(\mathrm{a}_{1 \mathrm{~g}} \rightarrow \mathrm{b}_{1 \mathrm{~g}}\right)$ electronic transitions respectively (Gup and Kirkan, 2006; Lima et al., 2008). Typical ultraviolet and visible spectra of these complexes are displayed in Figures 3 (Appendix). 
Table 4: UV-VIS spectral data of free ligands and their mixed metal complexes

\begin{tabular}{|c|c|c|c|c|c|}
\hline Compounds & $\begin{array}{l}\text { Intraligands } \\
\text { transition } \\
\left(\mathrm{cm}^{-1}\right)\end{array}$ & $\begin{array}{l}\text { Charge } \\
\text { transfer } \\
\left(\mathrm{cm}^{-1}\right)\end{array}$ & $\begin{array}{l}\text { Ligand } \\
\text { field } \\
\text { transition } \\
\left(\mathrm{cm}^{-1}\right)\end{array}$ & Assignment & \begin{tabular}{|l} 
Proposed \\
structure
\end{tabular} \\
\hline $\mathrm{L}_{1}$ & $\begin{array}{l}30,674, \\
33,333-34,965\end{array}$ & & & & \\
\hline$\left[\mathrm{Cu}\left(\mathrm{L}_{1}\right)(\mathrm{bpy})\left(\mathrm{H}_{2} \mathrm{O}\right)_{2}\right] \mathrm{Cl}$ & $32,051,33,112$ & & 14,450 & ${ }^{2} \mathrm{E}_{\mathrm{g}} \rightarrow{ }^{2} \mathrm{~T}_{2 \mathrm{~g}}$ & Octahedral \\
\hline$\left[\mathrm{Cu}\left(\mathrm{L}_{1}\right)(\mathrm{phen})\left(\mathrm{H}_{2} \mathrm{O}\right)_{2}\right] \mathrm{Cl}$ & $\begin{array}{l}34,013 \\
36,496\end{array}$ & & 14,164 & ${ }^{2} \mathrm{E}_{\mathrm{g}} \rightarrow{ }^{2} \mathrm{~T}_{2 \mathrm{~g}}$ & Octahedral \\
\hline$\left[\mathrm{Ni}\left(\mathrm{L}_{1}\right)(\mathrm{bpy})\left(\mathrm{H}_{2} \mathrm{O}\right)_{2}\right] \mathrm{Cl}$ & $\begin{array}{l}34,482,33,112 \\
30,487\end{array}$ & & $\begin{array}{l}14,409, \\
12,821 \\
11,710\end{array}$ & $\begin{array}{l}{ }^{3} \mathrm{~A}_{2 g}(\mathrm{~F}) \rightarrow{ }^{3} \mathrm{~T}_{1 g}(\mathrm{P}) \\
{ }^{3} \mathrm{~A}_{2 g}(\mathrm{~F}) \rightarrow{ }^{3} \mathrm{~T}_{1 g}(\mathrm{~F}) \\
{ }^{3} \mathrm{~A}_{2 g}(\mathrm{~F}) \rightarrow{ }^{3} \mathrm{~T}_{2 g}(\mathrm{~F})\end{array}$ & Octahedral \\
\hline$\left[\mathrm{Ni}\left(\mathrm{L}_{1}\right)(\right.$ phen $\left.)\left(\mathrm{H}_{2} \mathrm{O}\right)_{2}\right] \mathrm{Cl}$ & $\begin{array}{l}34,722,33,333, \\
30,120\end{array}$ & & $\begin{array}{l}15,625, \\
14,084, \\
11,834\end{array}$ & $\begin{array}{l}{ }^{3} \mathrm{~A}_{2 g}(\mathrm{~F}) \rightarrow{ }^{3} \mathrm{~T}_{1 g}(\mathrm{P}) \\
{ }^{3} \mathrm{~A}_{2 g}(\mathrm{~F}) \rightarrow{ }^{3} \mathrm{~T}_{1 g}(\mathrm{~F}) \\
{ }^{3} \mathrm{~A}_{2 g}(\mathrm{~F}) \rightarrow{ }^{3} \mathrm{~T}_{2 g}(\mathrm{~F})\end{array}$ & Octahedral \\
\hline $\mathrm{L}_{2}$ & $\begin{array}{l}30,488,33,333, \\
43103\end{array}$ & & & & \\
\hline$\left[\mathrm{Cu}\left(\mathrm{L}_{2}\right)(\mathrm{bpy})\left(\mathrm{H}_{2} \mathrm{O}\right)_{2}\right] \mathrm{Cl}$ & $\begin{array}{l}40,816,33,333, \\
32,258\end{array}$ & 47,619 & 14,327 & ${ }^{2} \mathrm{E}_{\mathrm{g}} \rightarrow{ }^{2} \mathrm{~T}_{2 g}$ & Octahedral \\
\hline$\left[\mathrm{Cu}\left(\mathrm{L}_{2}\right)(\mathrm{phen})\left(\mathrm{H}_{2} \mathrm{O}\right)_{2}\right] \mathrm{Cl}$ & $37,037,33,898$ & & 14,286 & ${ }^{2} \mathrm{E}_{\mathrm{g}} \rightarrow{ }^{2} \mathrm{~T}_{2 \mathrm{~g}}$ & Octahedral \\
\hline$\left[\mathrm{Ni}\left(\mathrm{L}_{2}\right)(\mathrm{bpy})\right] \mathrm{Cl}$ & 28,986 & 45,455 & $\begin{array}{l}19,231 \\
15,385\end{array}$ & $\begin{array}{l}{ }^{1} \mathrm{~A}_{1 \mathrm{~g}} \rightarrow{ }^{1} \mathrm{~B}_{1 \mathrm{~g}} \\
{ }^{1} \mathrm{~A}_{1 \mathrm{~g}} \rightarrow{ }^{1} \mathrm{~A}_{2 g}\end{array}$ & Square planar \\
\hline$\left[\mathrm{Ni}\left(\mathrm{L}_{2}\right)(\right.$ phen $\left.)\right] \mathrm{Cl}$ & 29,412 & 47,619 & $\begin{array}{l}15,503 \\
13,333\end{array}$ & $\begin{array}{l}{ }^{1} \mathrm{~A}_{1 \mathrm{~g}} \rightarrow{ }^{1} \mathrm{~B}_{1 \mathrm{~g}} \\
{ }^{1} \mathrm{~A}_{1 \mathrm{~g}} \rightarrow{ }^{1} \mathrm{~A}_{2 g}\end{array}$ & Square planar \\
\hline
\end{tabular}

\section{Magnetic susceptibility measurements}

The room temperature magnetic susceptibilities and effective magnetic moments of the mixed metal complexes prepared are given in Table 5. The magnetic moment of low-spin $\mathrm{d}^{8}$ nickel(II) complexes is expected to be zero and diamagnetic with a square planar geometry. The effective magnetic moment for the synthesized nickel(II) complexes of vanillinbenzoylhydrazone $\left(\mathrm{L}_{2}\right)$ mixed with 2,2 ${ }^{1}$-bipyridine and 1,10phenanthroline showed a magnetic moment of 0.49 B.M and 0.75 B.M respectively, these values are consistent for the $\mathrm{d}^{8}$ diamagnetic electronic configuration with square planar geometry. The slight increase in these magnetic moments are indicative of a low spin-high spin equilibrium mixture with some paramagnetic nickel(II) species in accordance with the interpretation of Woods and Patel, 1990. The magnetic moment of
2.78 and 3.11 B.M for nickel(II) complexes of 2anisaldehyde-benzoylhydrazone $\left(\mathrm{L}_{1}\right)$ mixed with 1,10-phenathroline and 2,2-bipyridine are consistent with those reported for octahedral geometry with $\mathrm{d}^{8}$ electronic configuration having two unpaired electrons. The magnetic susceptibilities of the synthesized copper(II) complexes of $2-\mathrm{ABH}\left(\mathrm{L}_{1}\right)$ and $\mathrm{VBH}\left(\mathrm{L}_{2}\right)$ mixed with 2,2-bipyridine and 1,10-phenanthroline are indicative of $\mathrm{d}^{9}$ electronic configuration with one unpaired electron. The effective magnetic moment of 2.14 - 2.36 B.M observed for the complexes are close to the range of 1.70 to 2.20 B.M usually observed for magnetically dilute copper(II) complexes with octahedral geometry (Greenwood and Earnshaw, 1984; Figgis, 1978). This is suggestive of a strong ferromagnetic interaction between the adjacent magnetic centers (Emeleus and Sharpe, 2008). 
Table 5: Magnetic susceptibility data of the mixed metal (II) complexes

\begin{tabular}{|l|l|l|l|l|l|}
\hline Compounds & $\begin{array}{l}\text { M.W } \\
\text { g/mol. }\end{array}$ & $\chi_{\mathrm{i}} \times 10^{6}$ & $\chi_{\mathrm{m}} \times 10^{6}$ & Temp. (K) & $\mu_{\text {eff }}(\mathrm{B} . \mathrm{M})$ \\
\hline$\left[\mathrm{Cu}\left(\mathrm{L}_{1}\right)(\right.$ bpy $\left.)\left(\mathrm{H}_{2} \mathrm{O}\right)_{2}\right] \mathrm{Cl}$ & 545.50 & -273.51 & 2313.61 & 295.5 & 2.21 \\
\hline$\left[\mathrm{Cu}\left(\mathrm{L}_{1}\right)(\right.$ phen $\left.)\left(\mathrm{H}_{2} \mathrm{O}\right)_{2}\right] \mathrm{Cl}$ & 569.52 & -285.51 & 2480.57 & 295.5 & 2.14 \\
\hline$\left[\mathrm{Ni}\left(\mathrm{L}_{1}\right)(\right.$ bpy $\left.)\left(\mathrm{H}_{2} \mathrm{O}\right)_{2}\right] \mathrm{Cl}$ & 540.64 & -263.51 & 3827.60 & 295.5 & 3.11 \\
\hline$\left[\mathrm{Ni}\left(\mathrm{L}_{1}\right)(\right.$ phen $\left.)\left(\mathrm{H}_{2} \mathrm{O}\right)_{2}\right] \mathrm{Cl}$ & 564.66 & -285.51 & 2979.80 & 295.7 & 2.78 \\
\hline$\left[\mathrm{Cu}\left(\mathrm{L}_{2}\right)(\right.$ bpy $\left.)\left(\mathrm{H}_{2} \mathrm{O}\right)_{2}\right] \mathrm{Cl}$ & 561.50 & -282.73 & 2363.68 & 296.0 & 2.25 \\
\hline$\left[\mathrm{Cu}\left(\mathrm{L}_{2}\right)(\right.$ phen $\left.)\left(\mathrm{H}_{2} \mathrm{O}\right)_{2}\right] \mathrm{Cl}$ & 585.52 & -294.73 & 2065.43 & 296.0 & 2.36 \\
\hline$\left[\mathrm{Ni}\left(\mathrm{L}_{2}\right)\right.$ (bpy) $] \mathrm{Cl}$ & 520.61 & -282.73 & -180.45 & 296.0 & 0.49 \\
\hline$\left[\mathrm{Ni}\left(\mathrm{L}_{2}\right)\right.$ (phen) $\left.)\right] \mathrm{Cl}$ & 544.63 & -294.66 & -51.53 & 296.0 & 0.75 \\
\hline
\end{tabular}

\section{Conductivity measurement}

The molar conductivities in DMF for all complexes are in the range 41.67-82.53 $\Omega^{-1} \mathrm{~cm}^{2}$ $\mathrm{mol}^{-1}$, indicating their electrolytic nature (Geary, 1971). These value showed that they are 1:1 electrolyte. The high values of molar conductance may be due to partial dissociation of the metal complexes in the solvent. The results obtained were in agreement with the proposed geometries for the metal complexes (Imran et al., 2013). The molar conductivity measurements are displayed in Table 6.

Table 6: Conductivity measurement of the metal complexes in $\left(\Omega^{-1} \mathrm{~cm}^{2} \mathrm{~mol}^{-1}\right)$

\begin{tabular}{|l|l|l|l|}
\hline Compounds & $\boldsymbol{\Lambda m}\left(\mathbf{\Omega}^{-1} \mathbf{c m}^{2} \mathbf{m o l}^{-1}\right)$ & Solvent & Electrolyte \\
\hline$\left[\mathrm{Cu}\left(\mathrm{L}_{1}\right)(\right.$ bpy $\left.)\left(\mathrm{H}_{2} \mathrm{O}\right)_{2}\right] \mathrm{Cl}$ & 62.87 & DMF & $1: 1$ \\
\hline$\left[\mathrm{Cu}\left(\mathrm{L}_{1}\right)(\right.$ phen $\left.)\left(\mathrm{H}_{2} \mathrm{O}\right)_{2}\right] \mathrm{Cl}$ & 63.52 & DMF & $1: 1$ \\
\hline$\left[\mathrm{Ni}\left(\mathrm{L}_{1}\right)(\right.$ bpy $\left.)\left(\mathrm{H}_{2} \mathrm{O}\right)_{2}\right] \mathrm{Cl}$ & 41.67 & DMF & $1: 1$ \\
\hline$\left[\mathrm{Ni}\left(\mathrm{L}_{1}\right)(\right.$ phen $\left.)\left(\mathrm{H}_{2} \mathrm{O}\right)_{2}\right] \mathrm{Cl}$ & 42.12 & DMF & $1: 1$ \\
\hline$\left[\mathrm{Cu}\left(\mathrm{L}_{2}\right)(\right.$ bpy $\left.)\left(\mathrm{H}_{2} \mathrm{O}\right)_{2}\right] \mathrm{Cl}$ & 70.48 & DMF & $1: 1$ \\
\hline$\left[\mathrm{Cu}\left(\mathrm{L}_{2}\right)(\right.$ phen $\left.)\left(\mathrm{H}_{2} \mathrm{O}\right)_{2}\right] \mathrm{Cl}$ & 59.96 & DMF & $1: 1$ \\
\hline$\left[\mathrm{Ni}\left(\mathrm{L}_{2}\right)(\right.$ bpy $\left.)\right] C l$ & 82.53 & DMF & $1: 1$ \\
\hline$\left[\mathrm{Ni}\left(\mathrm{L}_{2}\right)(\right.$ phen $\left.)\right] \mathrm{Cl}$ & 72.95 & DMF & $1: 1$ \\
\hline
\end{tabular}

\section{Antimicrobial Studies}

The synthesized compounds were tested against eleven micro-organisms consisting of six GramNegative and five Gram -Positive bacterial. The antimicrobial activity was carried out using a concentration of $10 \mathrm{mg} / \mathrm{ml}$ of synthesized compounds while streptomycin and ampicillin antibiotic were used as standard at a concentration of $1 \mathrm{mg} / \mathrm{ml}$. DMSO was used as solvent and as a negative control. $\left[\mathrm{Cu}\left(\mathrm{L}_{2}\right)\right.$ (phen) $\left.\left(\mathrm{H}_{2} \mathrm{O}\right)_{2}\right] \mathrm{Cl}$ showed the highest level of activity against all the tested micro-organisms with the exception of Klesiella. pneumonia and Proteus vulgaris. This is reflective in the zone of inhibition exhibited against all the tested organisms. All the compounds showed significant antimicrobial activities against Gram Negative bacteria strains that had been found to be resistant to most drugs. The tremendous antimicrobial activity of compounds viz: $\left[\mathrm{Cu}\left(\mathrm{L}_{1}\right)(\right.$ bpy $\left.)\left(\mathrm{H}_{2} \mathrm{O}\right)_{2}\right] \mathrm{Cl}, \quad\left[\mathrm{Cu}\left(\mathrm{L}_{1}\right)(\right.$ phen $\left.)\left(\mathrm{H}_{2} \mathrm{O}\right)_{2}\right] \mathrm{Cl}$, $\left[\mathrm{Cu}\left(\mathrm{L}_{2}\right)(\mathrm{phen})\left(\mathrm{H}_{2} \mathrm{O}\right)_{2}\right] \mathrm{Cl}$, a n d $\left[\mathrm{Cu}\left(\mathrm{L}_{2}\right)(\mathrm{bpy})\left(\mathrm{H}_{2} \mathrm{O}\right)_{2}\right] \mathrm{Cl}$ with the best antimicrobial activities could be due to the presence of heterocyclic compounds (2,2 -bipyridine and 1,10-phenanthroline) in the complexes which by synergistic effect enhanced the inhibitory activity. 
$\left[\mathrm{Ni}\left(\mathrm{L}_{2}\right)\right.$ (phen) $\left.\left(\mathrm{H}_{2} \mathrm{O}\right)_{2}\right] \mathrm{Cl}$ also had activity against the Gram Negative bacteria with the exception of Pseudomonas flourescens. Generally, the antimicrobial activities of all the synthesised compounds compare favourably with those of streptomycin and ampicillin used as the control and standard. The result for the zone of inhibition is shown in Table 7 while the graph showing the zone of inhibition of Ligands and metal complexes are displayed in Figures 4 and 5 respectively.

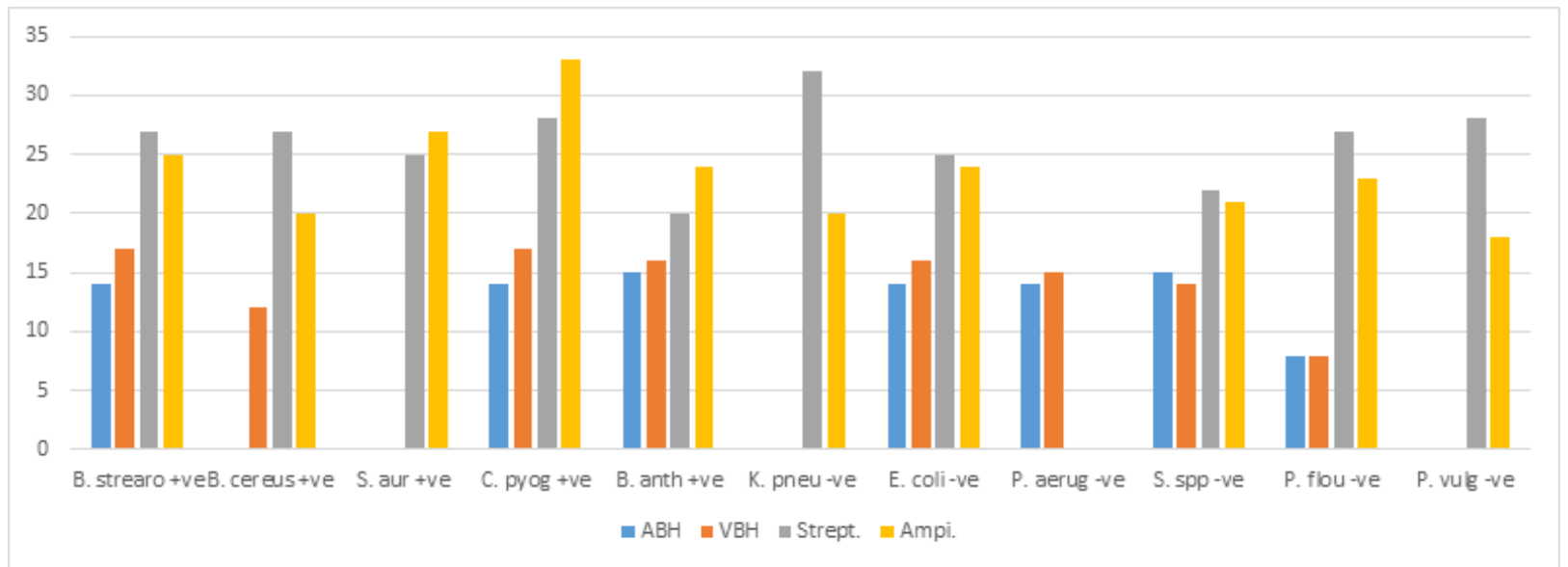

Figure 4:Graph of zone of inhibition of synthesized ligands against micro-organisms

Table 7: Antimicrobial activity data of the compounds $(10 \mathrm{mg} / \mathrm{ml})$ and controls.

\begin{tabular}{|c|c|c|c|c|c|c|c|c|c|c|c|}
\hline \multirow[b]{3}{*}{ Compounds } & \multirow[b]{3}{*}{$\begin{array}{l}\text { B. } \\
\text { strearo }\end{array}$} & \multirow{2}{*}{\multicolumn{2}{|c|}{$\begin{array}{l}\text { Gram- } \\
\text { positive }\end{array}$}} & \multirow[b]{3}{*}{ C. pyog } & \multicolumn{3}{|c|}{$\begin{array}{l}\text { Growth inhibition zone in } \\
\text { millimeter }(\mathrm{mm})\end{array}$} & \multirow[b]{3}{*}{ P. aerug } & \multirow[b]{3}{*}{ S. $s p p$} & \multirow[b]{3}{*}{ P. flou } & \multirow[b]{3}{*}{$\begin{array}{l}P . \\
\text { vulg }\end{array}$} \\
\hline & & & & & \multirow[b]{2}{*}{ B. anth) } & \multicolumn{2}{|c|}{ Gram-negative } & & & & \\
\hline & & B. cereus & S. aur & & & (K. pneu & E. coli & & & & \\
\hline$\left[\mathrm{Cu}\left(\mathrm{L}_{1}\right)(\mathrm{bpy})\left(\mathrm{H}_{2} \mathrm{O}\right)_{2}\right] \mathrm{Cl}$ & 0 & 11 & 9 & 18 & 10 & 0 & 10 & 0 & 10 & 6 & 0 \\
\hline$\left[\mathrm{Cu}\left(\mathrm{L}_{1}\right)(\right.$ phen $\left.)\left(\mathrm{H}_{2} \mathrm{O}\right)_{2}\right] \mathrm{Cl}$ & 0 & 20 & 0 & 32 & 0 & 0 & 14 & 12 & 12 & 7 & 0 \\
\hline$\left[\mathrm{Ni}\left(\mathrm{L}_{1}\right)(\mathrm{bpy})\left(\mathrm{H}_{2} \mathrm{O}\right)_{2}\right] \mathrm{Cl}$ & 13 & 10 & 15 & 13 & 13 & 0 & 12 & 14 & 12 & 8 & 12 \\
\hline$\left[\mathrm{Ni}\left(\mathrm{L}_{1}\right)(\right.$ phen $\left.)\left(\mathrm{H}_{2} \mathrm{O}\right)_{2}\right] \mathrm{Cl}$ & 13 & 8 & 14 & 0 & 16 & 0 & 12 & 0 & 0 & 11 & 14 \\
\hline$\left[\mathrm{Cu}\left(\mathrm{L}_{2}\right)(\mathrm{bpy})\left(\mathrm{H}_{2} \mathrm{O}\right)_{2}\right] \mathrm{Cl}$ & 32 & 29 & 13 & 37 & 20 & 0 & 23 & 16 & 21 & 20 & 0 \\
\hline$\left[\mathrm{Cu}\left(\mathrm{L}_{2}\right)(\right.$ phen $\left.)\left(\mathrm{H}_{2} \mathrm{O}\right)_{2}\right] \mathrm{Cl}$ & 25 & 8 & 18 & 28 & 15 & 17 & 13 & 16 & 16 & 16 & 17 \\
\hline$\left[\mathrm{Ni}\left(\mathrm{L}_{2}\right)(\mathrm{bpy})\right] \mathrm{Cl}$ & 0 & 7 & 12 & 0 & 0 & 12 & 14 & 10 & 18 & 0 & 0 \\
\hline$\left[\mathrm{Ni}\left(\mathrm{L}_{2}\right)\right.$ (phen) $] \mathrm{Cl}$ & 13 & 0 & 0 & 14 & 13 & 0 & 13 & 12 & 12 & 0 & 0 \\
\hline Streptomycin & 27 & 27 & 25 & 28 & 20 & 32 & 25 & 0 & 22 & 27 & 28 \\
\hline Ampicillin & 25 & 20 & 27 & 33 & 24 & 20 & 24 & 0 & 21 & 23 & 18 \\
\hline
\end{tabular}

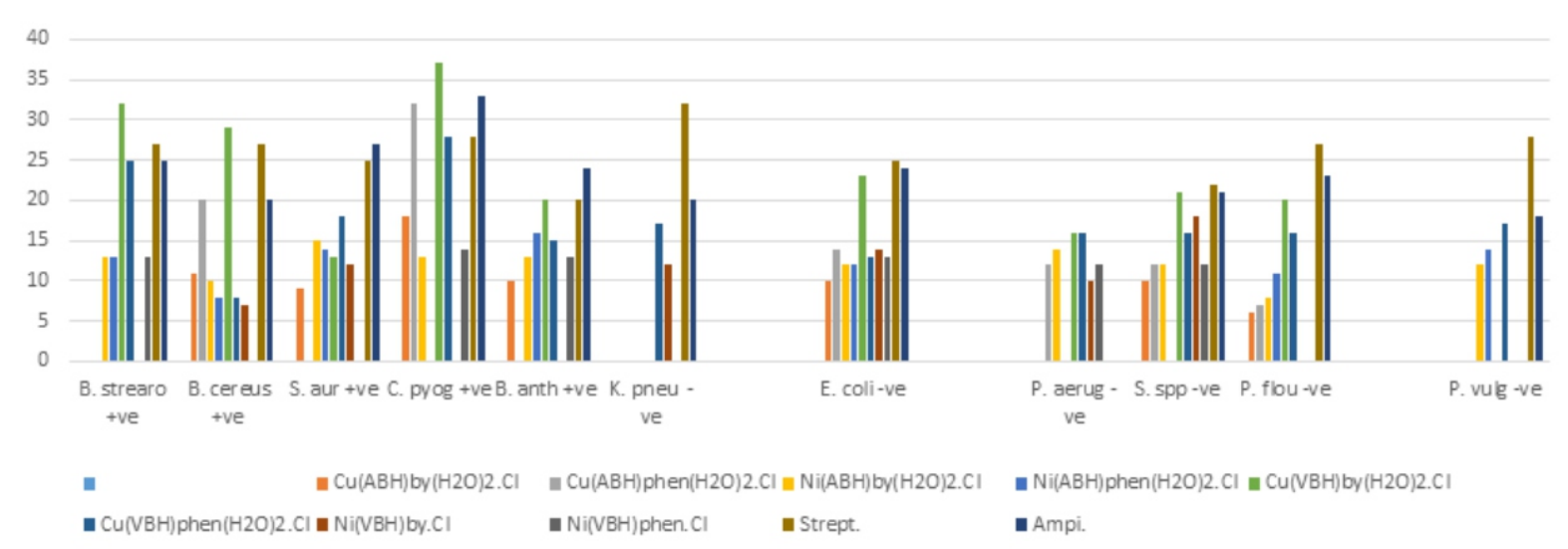

Figure 5: Graph of zone of inhibition metal complexes against micro-organi 


\section{CONCLUSIONS}

Two hydrazone ligands 2-anisaldehydebenzoylhydrazone $\left(\mathrm{L}_{1}\right)$ and vanillinbenzoylhydrazone $\left(\mathrm{L}_{2}\right)$, their mixed nickel (II) and copper (II) complexes with 2,2 -bipyridine and 1,10-phenanthroline ( $\mathrm{N}-\mathrm{N}$ bases) were prepared and characterized by physical and chemical methods. The nickel(II) complexes of the hydrazone ligands mixed with $2,2^{1}$-bipyridine and 1,10-phenathroline show colours ranging from deep green to orange while the colour of copper(II) complexes of the hydrazone ligands mixed with 2,2 ${ }^{1}$-bipyridine and 1,10phenathroline are generally green. The compounds are generally insoluble in water; they had a high melting point which revealed a high thermal stability of the complexes. Infrared spectra indicated that coordination of the ligands to the metal ions occurred via the azomethine nitrogen $(\mathrm{C}=\mathrm{N})$ and deprotonated carbonyl oxygen (=C?O-) suggesting that the ligands acted in a mononegative bidentate fashion. The percentage metal analysis suggested the stoichiometry of the mixed complexes to be 1:1:1 ratio for metal: ligand: $\mathrm{N}-\mathrm{N}_{\text {(base) }}$

The UV-VIS electronic spectra and magnetic moments for the mixed complexes of $\mathrm{Ni}$ (II) and $\mathrm{Cu}$ (II) suggested six coordinate octahedral geometries for the compounds with the exception of $\left[\mathrm{Ni}\left(\mathrm{L}_{2}\right)(\mathrm{bpy})\right] \mathrm{Cl}$ and $\left[\mathrm{Ni}\left(\mathrm{L}_{2}\right)(\right.$ phen $\left.)\right] \mathrm{Cl}$ that had a probable four coordinate square planar geometry. This observation was supported by the conductivity measurement values which revealed that the chloride ion is outside the coordination sphere.

The mixed ligand complexes of copper displayed moderate activity against the tested microorganisms where $\left[\mathrm{Cu}\left(\mathrm{L}_{1}\right)(\mathrm{bpy})\left(\mathrm{H}_{2} \mathrm{O}\right)_{2}\right] \mathrm{Cl}$, $\left[\mathrm{Cu}\left(\mathrm{L}_{1}\right)\right.$ (phen) $\left.\left(\mathrm{H}_{2} \mathrm{O}\right)_{2}\right] \mathrm{Cl},\left[\mathrm{Cu}\left(\mathrm{L}_{2}\right)(\right.$ phen $\left.)\left(\mathrm{H}_{2} \mathrm{O}\right)_{2}\right] \mathrm{Cl}$, and $\left[\mathrm{Cu}\left(\mathrm{L}_{2}\right)\right.$ (bpy) $\left.\left(\mathrm{H}_{2} \mathrm{O}\right)_{2}\right] \mathrm{Cl}$ had the best antimicrobial activities. This could be due to the presence of the heterocyclic bases (1, 10phenanthroline and 2, $2^{1}$-bipyridine) in the mixed metal (II) complexes which enhanced the biological properties by synergistic effect.

\section{PROPOSED STRUCTURES}

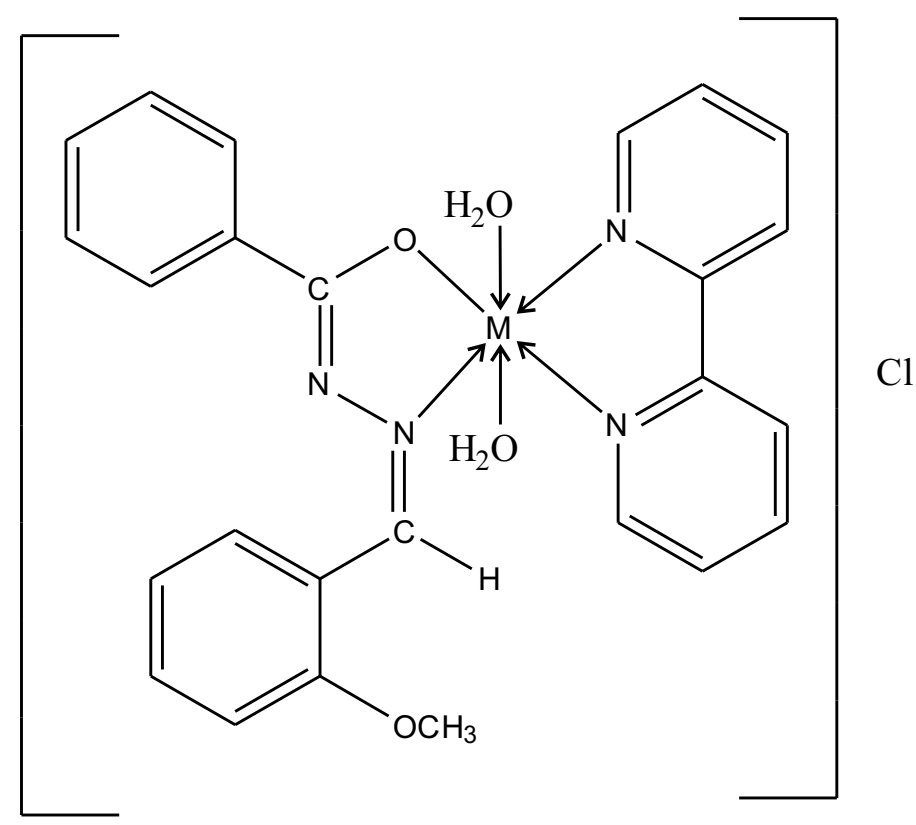

Figure 5: Proposed structure for $\left[\mathrm{Cu}\left(\mathrm{L}_{1}\right)(\mathrm{bpy})\left(\mathrm{H}_{2} \mathrm{O}\right)_{2}\right] \mathrm{Cl}$ and $\left[\mathrm{Ni}\left(\mathrm{L}_{1}\right)(\mathrm{bpy})\left(\mathrm{H}_{2} \mathrm{O}\right)_{2}\right] \mathrm{Cl}$ 


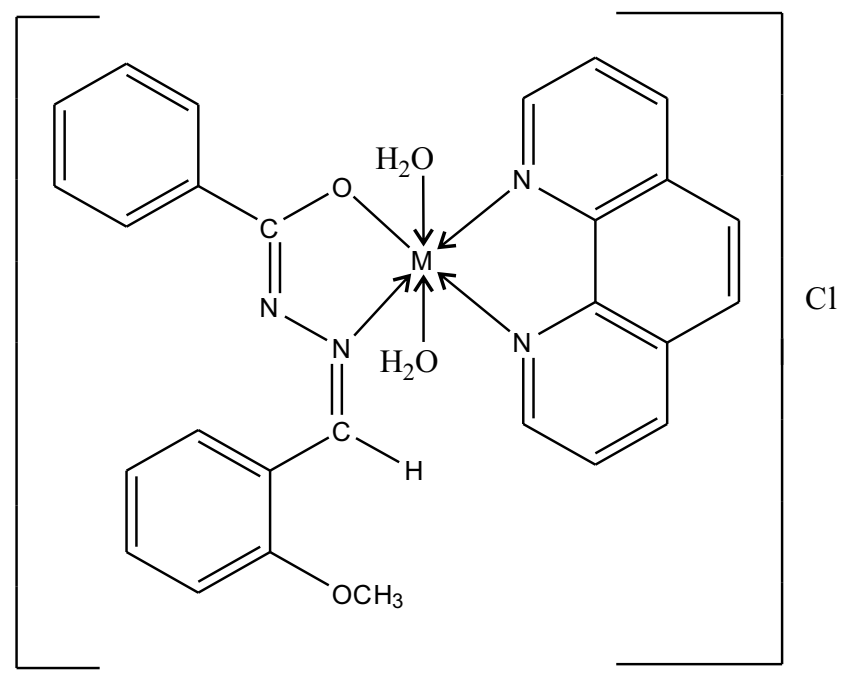

Figure 6: Proposed structure for $\left[\mathrm{Cu}\left(\mathrm{L}_{1}\right)(\right.$ phen $\left.)\left(\mathrm{H}_{2} \mathrm{O}\right)_{2}\right] \mathrm{Cl}$, and $\left[\mathrm{Ni}\left(\mathrm{L}_{1}\right)(\mathrm{phen})\left(\mathrm{H}_{2} \mathrm{O}\right)_{2}\right] \mathrm{Cl}$<smiles></smiles>

Figure 7: Proposed structure for $\left[\mathrm{Ni}\left(\mathrm{L}_{2}\right)(\mathrm{bpy})\right] \mathrm{Cl}$

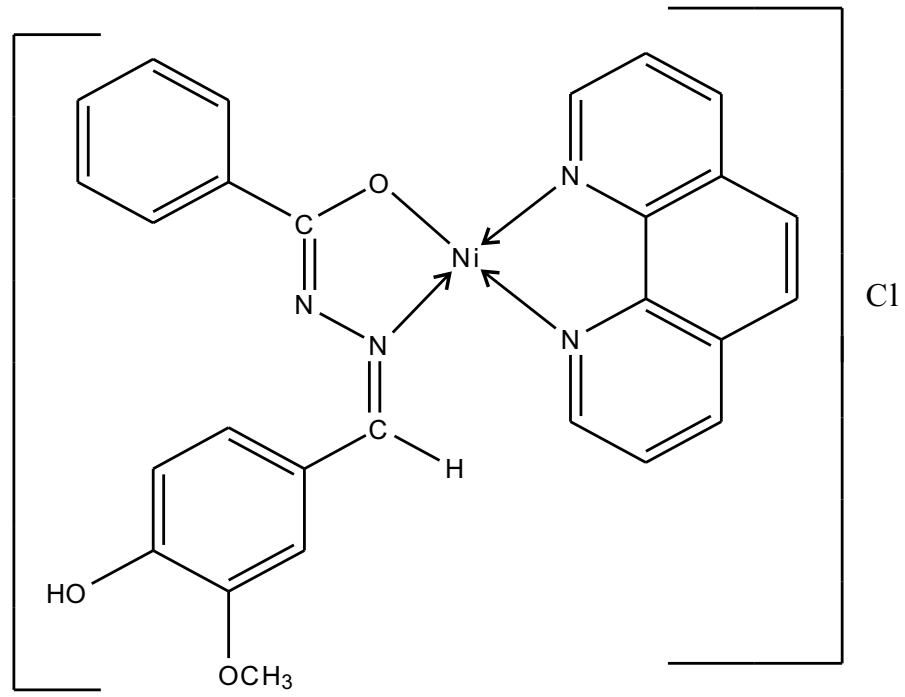

Figure 8: Proposed structure for $\left[\mathrm{Ni}\left(\mathrm{L}_{2}\right)(\mathrm{phen}] \mathrm{Cl}\right.$. 
APPENDICES

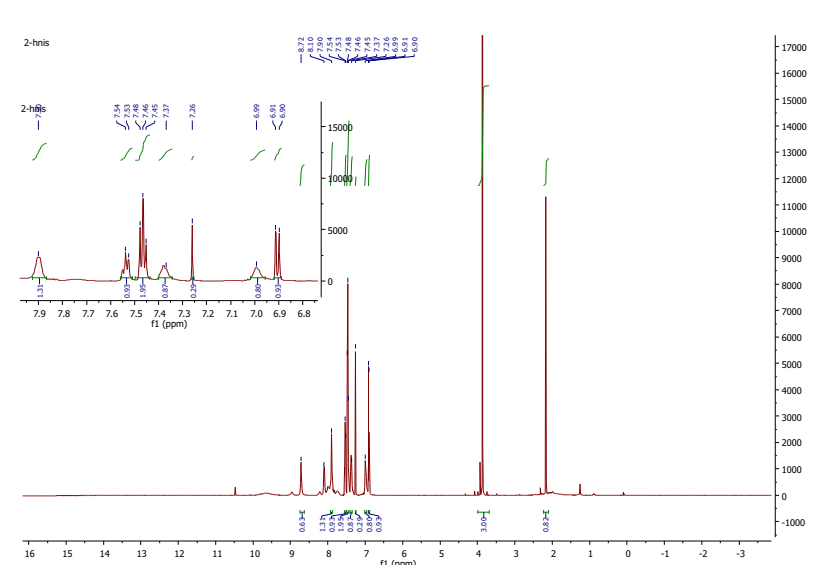

(a)

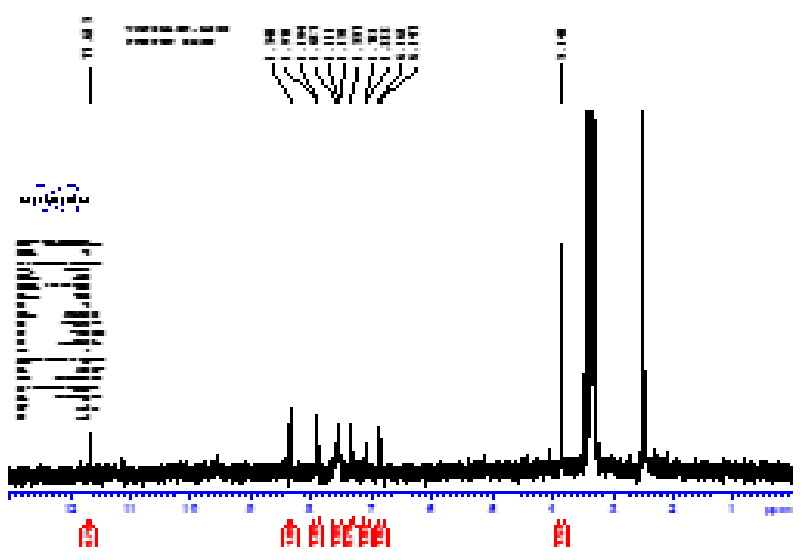

(b)

Figure 1: (a) ${ }^{1} \mathrm{HNMR}$ of 2-anisaldehyde-benzoylhydrazone $\left(\mathrm{L}_{1}\right)$ and (b) vanillin-benzoylhydrazone $\left(\mathrm{L}_{2}\right)$

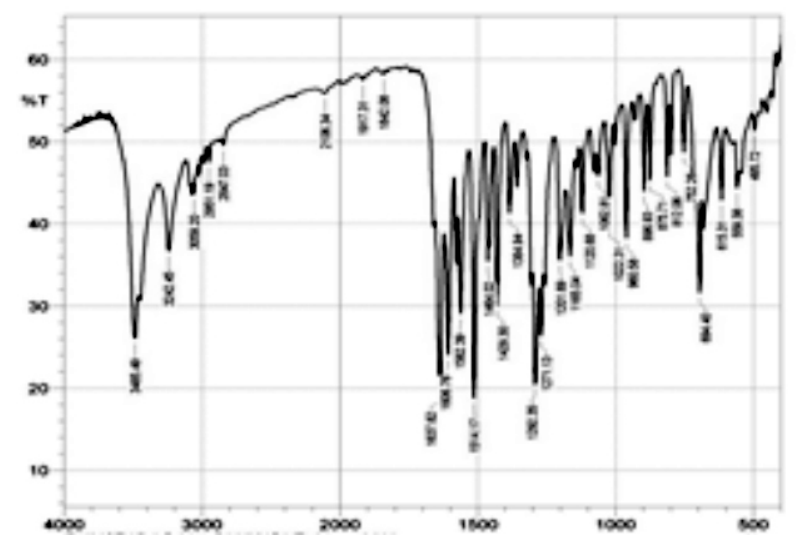

(a)

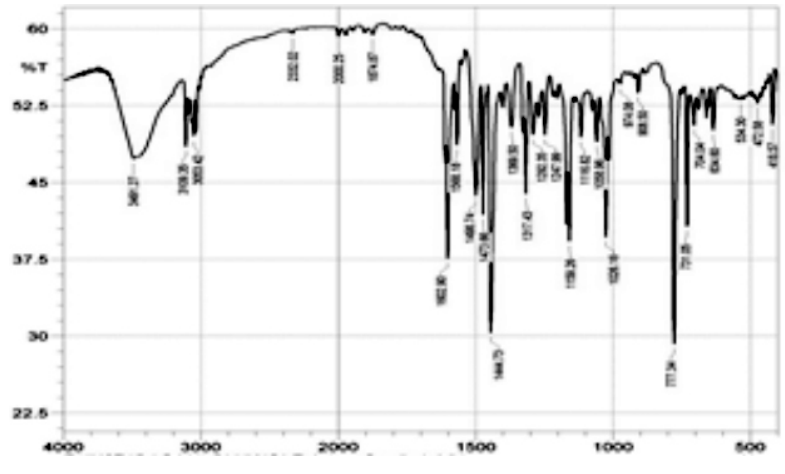

(b)

Figure 2. IR spectra of vanillin benzoylhydrazone $\left(\mathrm{L}_{2}\right)(\mathrm{a})$ and $\left[\mathrm{Cu}\left(\mathrm{L}_{2}\right)(\mathrm{bpy})\left(\mathrm{H}_{2} \mathrm{O}\right)_{2}\right] \mathrm{Cl}$ (b).

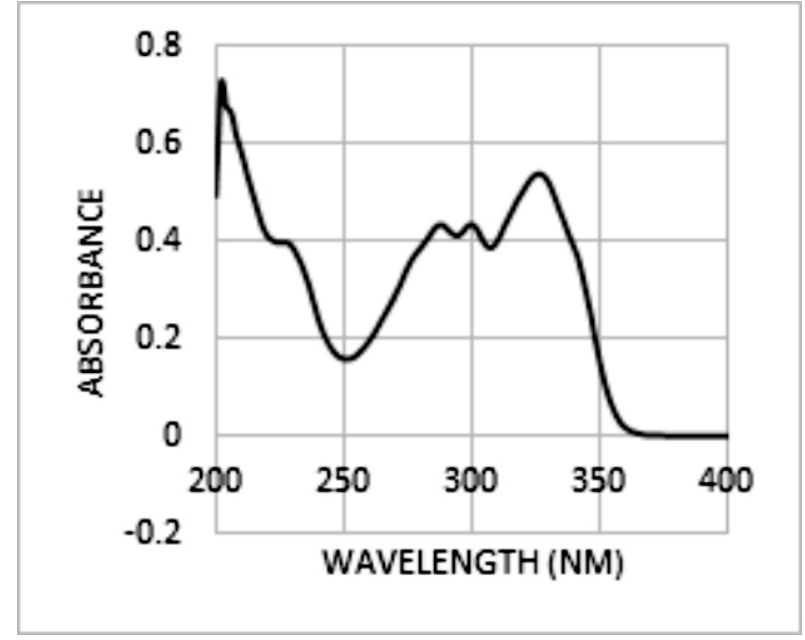

(a)

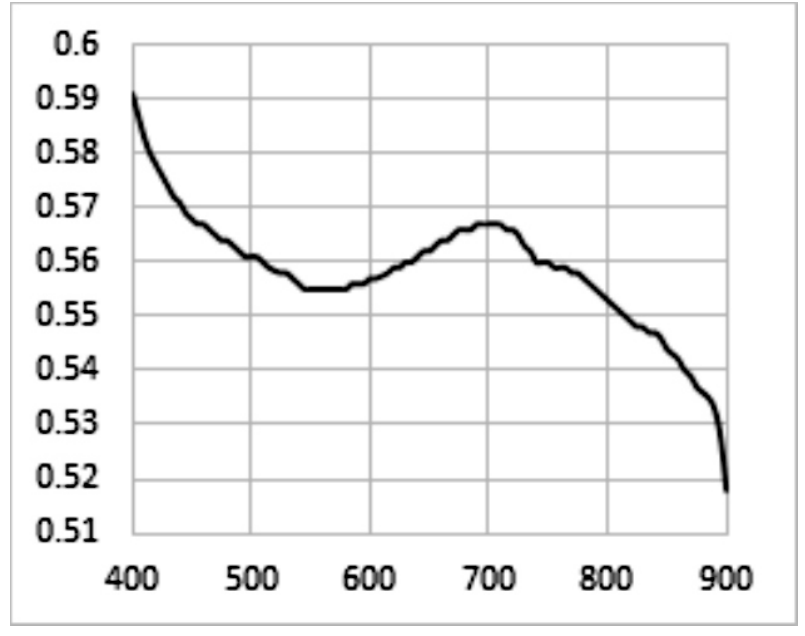

(b)

Figure 3 (a) UV of anisaldehyde -benzoylhydrazone (2-ABH); Visible spectrum of $\mathrm{Cu}(\mathrm{ABH})(\mathrm{bpy})\left(\mathrm{H}_{2} \mathrm{O}\right)_{2} \cdot \mathrm{Cl}$ (b) 


\section{REFERENCES}

Abdel-Aziz, H. A. and Mekawey, A. A. 2009. Stereoselective synthesis and antimicrobial activity of benzofuranbased (1E)-1-(piperidin-1-yl)-N2arylamidrazones. Eur J Med Chem. 44: 4985-4997.

Abdel-Wahab, B. F., Awad, G. E., Badria, F.A., 2011. Synthesis, antimicrobial, antioxidant, anti-hemolytic and cytotoxic evaluation of new imidazole-based heterocycles. Eur J Med Chem. 46:1505-1511.

Ahmed, S. A., Elghandour, A. H and Elgendy; H. S. 2014. Synthesis of pteridines derivatives from different heterocyclic compounds. DerPharma Chemica. 6(3):194-219.

Ainscough, E.W., Brodie, A.M., Dobbs, A.J., Ranford, J.D., 1998. Antitumour copper(II) salicylaldehyde benzoylhydrazone $\left(\mathrm{H}_{2} \mathrm{sb}\right)$ complexes: physicochemical properties and the single-crystal $\mathrm{X}$-ray structures of $\left[\left\{\mathrm{Cu}\left(\mathrm{H}_{2} \mathrm{sb}\right)\left(\mathrm{CCl}_{3} \mathrm{CO}_{2}\right)_{2}\right\}_{2}\right]$ and $[\{\mathrm{Cu}(\mathrm{Hsb})$ $\left.\left.\left(\mathrm{ClO}_{4}\right) \quad\left(\mathrm{C}_{2} \mathrm{H}_{5} \mathrm{OH}\right)\right\}_{2}\right]$ and the related salicylaldehyde acetylhydrazone $\left(\mathrm{H}_{2} \mathrm{sa}\right)$ complex, $\left[\mathrm{Cu}(\mathrm{Hsa}) \mathrm{Cl}\left(\mathrm{H}_{2} \mathrm{O}\right)\right] \mathrm{H}_{2} \mathrm{O}$. Inorg. Chem. Acta. 267, 27-38.

Agwara, M. O., Ndifon, P. T., Ndosiri, N. B., Paboudam, A. G., Yufanyi, D. M., Mohamadou, A. 2010. Synthesis, Characterisation and Antimicrobial Activities of Cobalt (II), Copper (II) and Zinc (II) Mixed-Ligand Complexes Containing 1,10-Phenanthroline and 2,2'Bipyridine. Bulletin of the Chemical Society of Ethiopia, 24(3), 383-389.

Al-Said M.S., Bashandy M.S., Al-Qasoumi S.I., Ghorab M.M. 2011. Anti-breast cancer activity of some novel 1,2dihydropyridine, thiophene and thiazole derivatives. Eur. J. Med. Chem. 46:137-141.

Al-sha'alan, N. H. 2007. Antimicrobial Activity and Spectral, Magnetic and Thermal Studies of Some Transition Metal Complexes of a Schiff Base Hydrazone Containing a Quinoline moiety. Molecules. 12: $1080-1091$.

Babahan, I., Coban, E. P., Biyik, H. 2013. Synthesis, characterisation and antimicrobial activities of vicdioxime derivatives containing heteroaromatic hydrazone groups and their metal complexes. Maejo IntJ Sci Technol7:26-41.

Chandra, S.,and Kumar U. 2005. Spectral and magnetic studies on manganese (II), cobalt (II) and nickel (II) complexes with Schiff bases. J. Spectrochim. Acta. Part A 61, 219-224.

Cotton, F. A.., Wilkinson, G., Murillo, C. A., Bochmann, M. 2003. Advanced Inorganic Chemistry, $6^{\text {th }}$ Ed.John Wiley and Sons Inc, New York.

Dandawate, P., Khan, E., Padhye, S., Gaba, H., Sinha S., Deshpande, J. 2012. Synthesis, characterization, molecular docking and cytotoxic activity of novel plumbagin hydrazones against breast cancer cells. Bioorg. Med. Chem. Lett. 22:3104-8.

Deepa, K. P and Aravindakshan, K. K. 2005. Synthesis, Characterization and Antifungal Studies of Metal Complexes of Benzoyl and Salicylhydrazones of $\omega$ Bromoacetanilide. Synthesis and Reactivity in Inorganic, Metal-Organic and Nano-Metal Chemistry 35: 409-416.

Emeleus, H.C and Sharpe, G.A. 2008. Inorganic Chemistry $3^{\text {rd }}$ Edition. Pearson Educational Limited England: pp 663668.

Earnshaw, A. and Greenwood, N.N, 1984. Chemistry of the Elements $1^{\text {st }}$ Ed. Oxford: Pergamon. pp 1380-1386.

Fattorusso C, Campiani G, Kukreja G, Persico M, Butini S, Romano MP,2008. Design, synthesis, and structure-activity relationship studies of 4-quinolinyl-and 9acrydinylhydrazones as potent antimalarial agents. J. Med. Chem. 51:1333-1343.

Figgis, B. N. 1978. Introduction to ligand fields; Wiley Interscience: NewYork, 1978.

Galal, S. A., Hegab, K. H., Kassab, A. S., Rodriguez, M. L., Kerwin S.M., ElDiwani, H. I. 2009 New transition metal ion complexes with benzimidazole-5carboxylic acid hydrazides with antitumor activity. Eur.J. Med. Chem. 44: 1500-1508.

Geary, W. J. 1971. The use of conductivity measurements in organic solvents for characterization of coordination 
compounds. J. Coord. Chem. Rev. 7:81-83.

Gökçe, M., Utku, S., Küpeli E. 2009. Synthesis and analgesic and anti-inflammatory activities 6-substituted-3(2H)-pyridazinone-2acetyl-2-(p-substituted/nonsubstituted benzal) hydrazone derivatives. Eur J Med Chem. 44: 3760-3764.

Govindasami T., Pandey A., Palanivelu N., Pandey A. 2011. Synthesis, characterization, and antibacterial activity of biologically important vanillin related hydrazone derivatives. Int J Org Chem. 1: 71-77.

Gup R., Kurkan, B., 2006. Synthesis and spectroscopic studies of mixed-ligand and polymeric dinuclear transition metal complexes with bis-acylhydrazone tetradentate ligands and 1,10phenanthroline. 64 (3), 809-815.

Hosny, M. M., Mahmound, M. A and Aly, R. E. M. 2010. 2-hydroxybenzaldehyde-(4, 6dimethylquinolin-2-yl)-hydrazone $(\mathrm{HBDH})$. Synthesis, characterization and ligational behaviour towards some metals. Synthesis and Reactivity in Inorganic, MetalOrganic and Nano-Metal Chemistry 40: 439-446.

Lima, L. M., Frattani, F. S., Dos Santos, J. L., Castro, H. C., Fraga, C. A., Zingali, R. B. 2008. Synthesis and anti-platelet activity of novel arylsulfonate - Acylhydrazone derivatives, designed as antithrombotic candidates. EurJ Med Chem. 43:348-456.

Neelmama, N., Venkateswar, R. P., Anuradha, G. H. 2010. Palladium (II) complexes of hydrazones derived from 4dodecyloxybenzoylhydrazine with some aliphatic and aromatic aldehydes and their mesogenic behavior; Indian Journal of Chemistry 48A: pp 1078-1084.

Patel K. S. and Woods J. A. O. 1990. Synthesis and physicochemical properties of bis(3-alkyl2,4 -pentanedionato)copper(II) complexes and their adducts with 2,2bipyridine and 1,10-phenanthroline. Synthesis and Reactivity of Inorganic and MetalOrganic Chemistry 20: 909-922.

Parrilha, G. L., Vieira, R. P., Rebollebo, A P., Isolda, C.and Lidia, M. 2010. Control of self-assembly through the influence of therminal hyroxymethyl groups on the metal coordination of pyrimidine- hydrazone $\mathrm{Cu}(\mathrm{II})$ complexes. Inorganic Chemistry 49(13): 5923 - 5934.

Patel, R. N., Singh, N., Shukla, K. K., Gundla, V. L. N.,Chauhan. U. K. 2006. Synthesis, characterization and biological activity of ternary copper(II) complexes containing polypyridyl ligands. Spectrochim. Acta. 63: 21-26.

Rollas, S and Küçükgüzel, S. G. 2007. Biological activities of hydrazone derivatives. Molecules 12:1910-1939.

Shen, X Y.Y., Jiang, H. L 1995. Lanthanide(III) complexes with hydrazone derived from a novel amino acid and isonicotinic acid hydrazide. Synthesis, characterization and antibacterial activity. Synthesis and Reactivity in Inorganic and Metal-Organic Chemistry 25: $511-526$.

Singh, J and Singh, P. 2012. Synthesis, spectroscopic characterization, and in vitro antimicrobial studies of pyridine-2carboxylic acid $\mathrm{N}$-(4-Chloro-Benzoyl)hydrazide and its $\mathrm{Co}(\mathrm{II}), \mathrm{Ni}(\mathrm{II})$, and $\mathrm{Cu}(\mathrm{II})$ complexes Hindawi Publishing Corporation. Bioinorganic Chemistry and Applications, doi:10.1155/2012/104549.

Singh, D. P., Malik, V., Kumar, K., Sharma, C., Aneja, K. R.. 2010. Macrocyclic metal complexes derived from 2,6diaminopyridine and isatin with their antibacterial and spectroscopic studies. Spectrochimica Acta $(A)$ 76: 45-49.

Sreeja, P. B., Prathapachandra, K. M .R., Kishore, A., Jasmin, C. 2004 . Spectral characterization, $\mathrm{X}$ - ray structure and biological investigations of copper (II) ternary complexes of 2 hydroxyacetophenone 4-hydroxybenzoic acid hydrazone and heterocyclic bases. Polyhedron 23: 575-581.

Walcourt A., Loyevsky M., Lovejoy D., Richardson D. R., 2004. Novel arylhydrazone and thiosemicarbazone iron chelators with anti-malarial activity against chloroquine- resistant and sensitive parasites. Int. Journal of Biochem and Cell Bio. 36 (3): 401-407.

Wang, Y W., He, S-Y, Liu, F., Chen F-Y., Wang, Y$\mathrm{Y}$ and Shi, Q-Z. 2008. Synthesis, characterization and crystal structures of $\mathrm{Ni}(\mathrm{II}), \mathrm{Cd}(\mathrm{II})$ complexes with N-(2- 
propionic acid)-salicyloyl hydrazone and bipy/phen. Journal of Coordination Chemistry 61(17):2703-2714.

Wang, Y. Yang L., Liu Z. Synthesis of novel hydrazone derivative and biophysical studies of its interactions with bovine serum by sopectroscopic, electrochemical and molecular docking methods. Chin. J. Org. Chem.33: 154-158. 